\title{
Pendidikan ekonomi dalam keluarga pemilik home industry Desa Jatimalang Kecamatan Klirong Kabupaten Kebumen
}

\author{
Aryani Purwaningrum, Hari Wahyono* \\ Universitas Negeri Malang, Jl. Semarang No. 5 Malang, Jawa Timur, Indonesia \\ *Penulis korespondensi, Surel: hari.wahyono.fe@um.ac.id
}

Paper received: 5-7-2021; revised: 23-7-2021; accepted: 30-7-2021

\begin{abstract}
This study aims to look at economic education in the family carried out by parents to children. All parents have taught family economic education in different ways. The importance of economic education in the family is to form children to use money rationally. As for economic education in the family, namely modeling, habits, discussion and communication, and consumption rationality. Researchers used qualitative research methods with a phenomenology approach. The technique used in this research is purposive sampling. The data technique is done by observing, interviewing and documenting. Parents' awareness to teach economic education in the family is high. By doing intense learning and full motivation from parents, children will quickly understand and apply it in everyday life.
\end{abstract}

Keywords: family economic education; consumption rationality; parenting style

\begin{abstract}
Abstrak
Penelitian ini bertujuan untuk melihat pendidikan ekonomi dalam keluarga yang dilakukan oleh orang tua kepada anak. Semua orang tua telah mengajarkan pendidikan ekonomi keluarga dengan cara yang berbeda. Pentingnya pendidikan ekonomi dalam keluarga adalah membentuk anak untuk menggunakan uang secara rasional. Adapun pendidikan ekonomi dalam keluarga yaitu keteladanan, kebiasaan, diskusi dan komunikasi, dan rasionalitas konsumsi. Peneliti menggunakan metode penelitian kualitatif dengan pendekatan fenomenologi. Teknik yang digunakan dalam penelitian ini adalah purposive sampling. Teknik data dilakukan dengan observasi, wawancara dan dokumentasi. Kesadaran orang tua untuk mengajarkan pendidikan ekonomi dalam keluarga cukup tinggi. Dengan melakukan pembelajaran yang intensif dan penuh motivasi dari orang tua, anak akan cepat memahami dan menerapkannya dalam kehidupan sehari-hari.
\end{abstract}

Kata kunci: pendidikan ekonomi keluarga; rasionalitas konsumsi; pola asuh

\section{Pendahuluan}

Organisasi Kesehatan Dunia (WHO) menemukan pertama kali serta melaporkan coronavirus di Wuhan, salah satu kota di China. Virus ini dikenal dengan covid-19. Dalam waktu singkat virus ini menyebar ke beberapa negara di dunia. Pandemi covid-19 terjadi pertama di Indonesia sejak tanggal 2 Maret 2020. Dalam waktu singkat penyebaran di Indonesia semakin meluas, pembatasan sosial mulai diberlakukan. Penurunan aktivitas berdampak ke berbagai sektor di Indonesia salah satunya yaitu sektor ekonomi. Badan Pusat Statistik menjelaskan dari hasil survei dampak covid-19 terhadap pelaku usaha yang dilakukan terhadap 34.559 responden atau pelaku usaha, sebesar 2,55\% mengalami peningkatan, $14,60 \%$ penghasilan tetap dan $82,85 \%$ mengalami penurunan pendapatan. Persentase penurunan pendapatan paling banyak dialami oleh usaha mikro kecil (UMK), dengan jumlah $84,20 \%$. 
Saat ini biaya hidup sangat tinggi, hal ini ditambah dengan menurunnya pendapatan akibat pandemi. Pengurangan pendapatan akan berdampak pada pengelolaan keuangan dalam keluarga. Pengelolaan keuangan keluarga yang baik saat pandemi ini sangat diperlukan karena kebutuhan akan tetap dan cenderung bertambah namun pendapatan berkurang. Oleh karena itu pentingnya pendidikan ekonomi di keluarga terutama kepada anak. Orang tua dapat mengajarkan dan mencontohkan secara langsung kepada anak mengenai pendidikan ekonomi di lingkungan keluarga.

Pendidikan yang pertama dan utama adalah keluarga, karena dalam keluarga seorang anak mendapatkan bimbingan dan pendidikan dasar. Sehingga orang tua harus menanamkan nilai-nilai yang sangat diperlukan bagi perkembangan kepribadian anak-anaknya agar anak akan tumbuh menjadi pribadi yang tangguh, mandiri dan memiliki sifat-sifat yang baik. Definisi keluarga secara operasional adalah suatu struktur yang bersifat khusus, satu sama lain dalam keluarga mempunyai ikatan melalui hubungan darah atau pernikahan, Hammudah Abd Al-Ati (dalam Bafadhol, 2017). Di keluarga seorang anak akan berinteraksi ayah, ibu, dan anggota keluarga lainnya, dimana seorang anak akan memperoleh pendidikan nonformal berupa kebiasaan, Idi (2011). Menurut Wahyono, (2001) keteladanan dan sikap keseharian orang tua serta intensitas dalam komunikasi antara anak dan orang tua dalam kehidupan keluarga memiliki peran yang sangat penting bagi pendidikan ekonomi. Menurut Wahyono, (2001) ada empat indikator intensitas pendidikan ekonomi dalam keluarga yaitu, keteladanan, penjelasan verbal, tuntutan perilaku yang relevan dan diskusi atas kasus yang relevan.

Pendidikan ekonomi di lingkungan keluarga bertujuan untuk mendidik anak agar tidak berperilaku konsumtif terutama di kalangan remaja yang sudah mengenal gaya hidup di luar lingkungan keluarga. Menurut Wulandari \& Narmaditya, (2015) perilaku konsumsi yang terjadi di kalangan remaja dipengaruhi oleh pendidikan di keluarga yaitu melalui pembiasaan, keteladanan dan penjelasan akan membentuk sebuah pola pikir. Perilaku, sikap serta nilai-nilai yang ditanamkan oleh orang tua sejak dini merupakan landasan bagi perkembangan tingkah laku anak selanjutnya.

Pendidikan ekonomi dalam keluarga merupakan lingkungan yang utama karena sebagian besar anak akan belajar tentang cara bertindak secara rasional sesuai prinsip ekonomi. Orang tua sebagai pendidik pertama harus memberikan contoh dan pembelajaran terkait contoh perilaku ekonomi yang baik. Anak diberikan pendidikan untuk mengenal uang dan mengetahui cara menggunakan serta bagaimana cara mendapatkannya. Salah satunya yaitu pengelolaan uang yang didapatkan dari orang tua, apakah uang yang didapatkan dihabiskan semua untuk konsumsi atau sebagian uang yang didapatkan untuk ditabung. Keuntungan pendidikan ekonomi di masa depan yaitu anak akan lebih mandiri karena sejak kecil anak sudah diajarkan untuk mengelola uang yang dimiliki.

Berdasarkan penelitian awal yang dilakukan oleh peneliti pada Rabu, 9 Desember 2020, bahwa home industry tahu merupakan pekerjaan utama dan adanya penurunan pendapatan sejak adanya pandemi disebabkan oleh permintaan konsumen berskala besar seperti pondok pesantren menurun, bahan baku yang semakin mahal tidak sebanding dengan penjualan, pembelian pedagang kaki lima yang menggunakan bahan baku tahu mengurangi pesanan dan bantuan sembako dari pemerintah juga dapat mengurangi pembelian tahu oleh masyarakat. Adanya perbedaan pendidikan ekonomi dalam keluarga sebelum dan sesudah pandemi. 
Pendidikan ekonomi yang diajarkan oleh setiap keluarga akan berbeda-beda. Proses dan pola yang diajarkan juga akan membentuk perilaku, sikap dan pola pikir anak yang berbedabeda seperti halnya dengan anak pemilik home industry tahu Desa Jatimalang Kecamatan Klirong Kabupaten Kebumen. Dampak pandemi berakibat pada penghasilan yang didapatkan. Tentunya akan berdampak pada pengelolaan keuangan keluarga, karena kebutuhan yang tetap namun penghasilan yang menurun. Peneliti ingin mengetahui dampak pandemi terhadap pendidikan ekonomi dalam keluarga kepada anak selain itu juga ingin mengetahui tentang rasionalitas konsumsi anak dari hasil menabung. Oleh karena itu, penulis tertarik untuk melakukan penelitian yang berjudul "Pendidikan Ekonomi Keluarga Home Industry Tahu Desa Jatimalang Kecamatan Klirong Kabupaten Kebumen".

\section{Metode}

Peneliti menggunakan metode penelitian kualitatif dengan pendekatan fenomenologi. Penelitian kualitatif merupakan penelitian ilmiah yang mengedepankan proses interaksi komunikasi dengan mendalam antara peneliti dan fenomena yang akan diteliti. Tujuan dari penelitian fenomenologi adalah mendeskripsikan pemaknaan umum dari setiap individu melalui pengalaman hidup. Fenomena yang diungkap yaitu dampak pandemi terhadap pendidikan ekonomi dalam keluarga kepada anak, selain itu juga ingin mengetahui tentang rasionalitas konsumsi anak dari hasil menabung.

Dalam pemilihan subjek, peneliti menggunakan teknik purposive sampling yang berarti peneliti memilih subjek dengan kriteria sebagai berikut: (1) pemilik home industry tahu di Desa Jatimalang, Kecamatan Klirong, Kabupaten Kebumen, (2) Home industry sebagai pekerjaan yang utama, dan (3) pemilik home industry tahu minimal 10 tahun. Teknik pengumpulan data yang dilakukan dalam penelitian ini yaitu: (1) observasi, (2) wawancara, dan (3) dokumentasi. Tahapan-tahapan analisis data dalam penelitian ini melalui tiga tahap yaitu: (1) reduksi data, (2) penyajian data, dan (3) verifikasi data. Dalam mengetahui keabsahan data, peneliti melakukan dua jenis triangulasi, yaitu: (1) triangulasi teknik, (2) triangulasi sumber.

\section{Hasil dan Pembahasan}

\subsection{Hasil Penelitian}

Informan penelitian ini yaitu orang tua dan anak pemilik home industry tahu yang menjadi subjek penelitian guna memberikan informasi terkait pendidikan ekonomi dalam keluarga. Penelitian ini dilakukan pada lima informan yang sesuai dengan kriteria peneliti yaitu pemilik home industry Desa Jatimalang Kecamatan Klirong Kabupaten Kebumen. Latar belakang informan merupakan pemilik home industry aktif yang sudah menjalankan usahanya lebih dari 10 tahun dan usaha home industry merupakan pekerjaan utama.

Berdasarkan penelitian yang dilakukan oleh peneliti ditemukan bahwa intensitas pendidikan ekonomi dalam keluarga di masa pandemi lebih sering dilakukan karena waktu dirumah antara orang tua dan anak lebih banyak. 


\section{Tabel 1. Temuan Penelitian}

\begin{tabular}{|c|c|c|}
\hline No & Indikator & Temuan Penelitian \\
\hline 1. & Keteladanan & $\begin{array}{l}\text { Intensitas pendidikan ekonomi dalam keluarga pada } \\
\text { saat pandemi covid-19 lebih sering dilakukan orang tua } \\
\text { dari pada sebelum adanya pandemi. } \\
\text { Keempat dari lima informan mengajak anaknya untuk } \\
\text { membantu dalam home industry tahu. }\end{array}$ \\
\hline 2. & Pembiasaan & $\begin{array}{l}\text { Uang Saku } \\
\text { Ketiga dari kelima informan mengurangi uang saku } \\
\text { kepada anak dengan sebelum adanya pandemi. } \\
\text { Menabung } \\
\text { Keempat dari kelima informan mengajarkan anaknya } \\
\text { untuk menabung. Antara lain dengan cara memberikan } \\
\text { fasilitas celengan untuk tempat menabung dan } \\
\text { memberikan motivasi untuk selalu menyisihkan uang } \\
\text { saku untuk ditabung. } \\
\text { Hidup Hemat } \\
\text { Kelima informan mengajarkan hidup hemat kepada } \\
\text { anak. Ditambah dengan adanya pandemi } \\
\text { mengakibatkan pendapatan berkurang informan } \\
\text { mengurangi pengeluaran biaya. }\end{array}$ \\
\hline 3. & $\begin{array}{l}\text { Diskusi dan } \\
\text { Komunikasi }\end{array}$ & $\begin{array}{l}\text { Kelima informan melakukan diskusi yang berkaitan } \\
\text { dengan masalah ekonomi dengan anak. }\end{array}$ \\
\hline 4. & Rasionalitas Konsumsi & $\begin{array}{l}\text { Kelima informan memiliki tujuan masing-masing dalam } \\
\text { menabung. Selain itu bentuk menabung informan juga } \\
\text { berbeda-beda, seperti di bank, mengikuti arisan dan } \\
\text { memelihara hewan ternak. } \\
\text { Dengan penanaman pendidikan ekonomi dalam } \\
\text { keluarga sejak dini mengakibatkan anak secara tidak } \\
\text { langsung membentuk sikap rasional dalam } \\
\text { berkonsumsi. }\end{array}$ \\
\hline
\end{tabular}

\subsection{Pembahasan}

Berikut ini merupakan pembahasan penelitian yang sudah dilakukan sesuai dengan fokus penelitian yang dapat menjawab hasil penelitian:

\subsubsection{Pendidikan Ekonomi Keluarga Melalui Keteladanan}

Pendidikan ekonomi keluarga melalui keteladanan merupakan salah satu hal yang dapat diterapkan orang tua kepada anak. Sejalan dengan pendapat Helmawati (2016) yang menyatakan bahwa keteladanan merupakan hal yang paling berpengaruh bagi anak. Sejalan dengan pendapat Wahyono (2001) dalam kehidupan keluarga, keteladanan dan sikap keseharian orang tua serta dengan intensitas komunikasi antara orang tua dan anak memiliki peran penting dalam pendidikan ekonomi. Salah satu bentuk keteladanan orang tua yaitu melalui pembiasaan. Kebiasaaan yang dilakukan oleh orang tua akan berdampak baik kepada anak.

Orang tua mengajak anaknya untuk membantu di home industry tahu. Namun, orang tua tidak memaksakan anak selalu membantu pekerjaan orang tua, ketika sudah lelah dengan aktivitas anak tersebut orang tua membebaskan anaknya untuk beristirahat. Yang paling 
sederhana anak dapat membantu memindahkan tahu yang sudah dicetak serta di potongpotong kedalam wadah untuk selanjutnya di goreng. Selain itu dipagi hari anak juga dapat membantu mengemas tahu ke kemasan plastik yang kecil untuk selanjutnya dipasarkan. Setelah proses produksi selesai anak membantu membereskan peralatan serta perlengkapan produksi untuk digunakan di produksi hari berikutnya. Dalam memberikan pendidikan melalui keteladanan, orang tua menerapkan pola asuh demokratis.

\subsubsection{Pendidikan Ekonomi Keluarga Melalui Pembiasaan}

\subsubsection{Pemberian Uang Saku}

Intensitas pemberian uang saku orang tua kepada anak dapat diberikan dalam harian, mingguan dan bulanan. Pemberian intensitas uang saku yang berbeda dapat disebabkan kebutuhan anak serta disesuaikan dengan umur anak. Untuk anak yang masih kecil dilatih untuk memegang uang saku dengan jumlah yang terbatas setiap harinya. Selain itu orang tua juga menjelaskan untuk berhati-hati ketika menggunakan uang karena untuk mendapatkannya tidaklah mudah. Sejalan dengan pernyataan yang disampaikan Wahyono (2001) yaitu pemahaman anak atas nilai uang sebaiknya menyadarkan anak bahwa untuk mendapatkannya tidak mudah serta diperlukan kerja keras, sehingga diperlukan kehati-hatian dalam memanfaatkannya. Selain itu orang tua juga melatih anaknya untuk tidak menghabiskan uang saku yang artinya harus menyisihkan untuk ditabung. Hal ini didukung pernyataan yang disampaikan oleh Wahyono (2001) bahwa kehidupan ekonomi dalam sehari-hari tidak terlepas dari masalah uang, biasanya di lingkungan keluarga, pendidikan ekonomi menitikberatkan pada pemahaman tentang nilai uang dan menanamkan sikap serta perilaku anak untuk mengatur pemanfaatan uang sesuai dengan prinsip ekonomi yang rasional. Pola asuh yang diterapkan dalam pemberian uang saku kepada anak yaitu pola asuh otoriter dan pola asuh situasional.

\subsubsection{Pembinaan Untuk Rajin Menabung}

Orang tua yang mengajarkan anaknya menabung sejak kecil akan berdampak besar pada pengelolaan keuangan anak dimasa mendatang. Sejalan dengan pernyataan menurut Krisdayanthi (2019) penerapan metode gemar menabung pada anak usia dini adalah kegiatan positif serta sangat membantu pengelolaan keuangan di masa mendatang. Dalam penerapannya orang tua selalu mengajarkan untuk menyisihkan uang saku. Untuk yang masih sekolah dibiasakan untuk menabung setiap hari. Selain itu fasilitas yang diberikan oleh orang tua, sederhananya yaitu membelikan celengan agar anak lebih termotivasi untuk menyisihkan uang sakunya. Orang tua yang menanamkan strategi menabung kepada anak dengan cara kebiasaan menabung di rumah sebagai kegiatan yang menyenangkan dan strategi menetapkan tujuan menabung Krisdayanthi (2019). Selain itu anak juga perlu motivasi dari orang tua agar dapat konsisten dalam menabung. Sejalan dengan pernyataan Helmawati (2016) yaitu sebagai pendidik yang pertama dan utama, orang tua hendaknya memberikan motivasi kepada anak agar anak dapat mengembangkan seluruh potensi yang dimilikinya. Penerapan pola asuh dalam mendidik anak untuk menabung yaitu pola asuh demokratis dan pola asuh situasional. 


\subsubsection{Pembinaan Untuk Berhemat}

Setiap keluarga memiliki cara masing-masing untuk menerapkan hidup hemat serta mengajarkannya ke anak. Orang tua dapat menjelaskan langsung kepada anak bagaimana cara hidup hemat, selain itu orang tua juga dapat mencontohkan agar anak lebih mengerti. Ketika anak sudah terbiasa dengan sikap berhemat yang diterapkan oleh orang tua, maka anak akan bisa mengontrol dirinya sendiri untuk menggunakan uang dengan sebijak mungkin dan membeli sesuai kebutuhan. Persiapan berhidup hemat dapat dimulai melalui pembiasaan. Menurut Helmawati (2016) pembiasaan adalah suatu keadaan yang dilakukan seseorang dengan mengaplikasikan perilaku-perilaku yang belum pernah atau jarang dilakukan menjadi sering dilakukan hingga pada akhirnya menjadi kebiasaan. Pengurangan pendapatan akibat dampak covid-19 serta diperlukan penyesuaian dengan kondisi dan situasi yang ada mengharuskan orang tua mengurangi pengeluaran seperti untuk kebutuhan hidup yang tidak terlalu diperlukan. Sesuai dengan hasil penelitian oleh Siyamto \& Saputra (2020) yaitu pada umumnya demi menghemat anggaran keluarga, para keluarga lebih mementingkan pemenuhan kebutuhan pangan, tagihan dan pendidikan. Pola asuh yang diterapkan orang tua untuk mengajarkan hidup hemat kepada anak yaitu pola asuh demokratis dan pola asuh situasional.

\subsubsection{Pendidikan Ekonomi Keluarga Melalui Diskusi dan Komunikasi}

Salah satu pendidikan ekonomi dalam keluarga yaitu diskusi atas kasus-kasus tentang masalah ekonomi. Orang tua dapat mulai berkomunikasi tentang permasalahan yang terjadi sehari-hari. Bukan hanya berdiskusi tentang permasalahan ekonomi yang sedang terjadi saja. Orang tua dapat melakukan komunikasi dan diskusi dengan intensitas yang tinggi kepada anak tentang pendidikan ekonomi dalam keluarga. Ketika sedang berdiskusi orang tua juga dapat menanyakan bagaimana pendapat anak mengenai topik yang sedang dibahas. Keterbukaan orang tua dalam mempersilahkan anaknya untuk berpendapat serta dapat mempertimbangkan dan menerima pendapat dari anak akan menjadi awal yang baik. Dalam kondisi tersebut anak merasa dihargai dalam berpendapat. Hal ini merupakan langkah pertama yang dapat dilakukan oleh semua orang tua untuk mengajarkan anak mengenai pendidikan ekonomi dalam keluarga. Komunikasi yang baik akan berdampak pada pesan yang akan disampaikan. Penerapan pola asuh atas pendidikan ekonomi keluarga melalui komunikasi dan diskusi kasus-kasus permasalahan ekonomi yang relevan yaitu, pola asuh demokratis dan pola asuh situasional.

\subsubsection{Rasionalitas Konsumsi}

Seharusnya dalam berkonsumsi anak lebih mengutamakan kebutuhan daripada keinginan. Keputusan anak dalam berkonsumsi sangatlah penting agar dapat mengontrol pengeluaran serta pengelolaan keuangan yang baik. Selain itu anak dalam berkonsumsi anak juga harus memilih sesuai dengan kemampuan atau yang dapat disebut juga sebagai strategi dalam berkonsumsi. Sesuai dengan pernyataan Wulandari \& Narmaditya (2015) yaitu pola pemenuhan kebutuhan berdasarkan strategi dalam berkonsumsi dan motif perilaku konsumsi merupakan indikasi dari perilaku konsumsi.

Jika anak sudah melakukan perilaku konsumsi secara rasional maka anak akan mempertimbangkan kegunaan dari barang yang akan dipilih. Kegunaan seperti dibutuhkan 
anak yang masih usia sekolah yaitu perlengkapan alat tulis dan dalam masa pandemi covid-19 pembelajaran dilakukan melalui daring, kuota internet menjadi kebutuhan utama anak. Hal ini dapat dilakukan dengan melalui penanaman nilai-nilai yang baik agar dapat membentuk perilaku konsumsi yang baik pula. Sesuai dengan pernyataan Wulandari \& Narmaditya (2015) yaitu penanaman nilai-nilai dalam keluarga yang baik akan membentuk perilaku konsumsi secara rasional. Penerapan pola asuh pendidikan ekonomi dalam keluarga melalui rasionalitas konsumsi adalah pola asuh demokratis dan pola asuh situasional.

\section{Gambar 1. Diagram pendidikan ekonomi dalam keluarga}

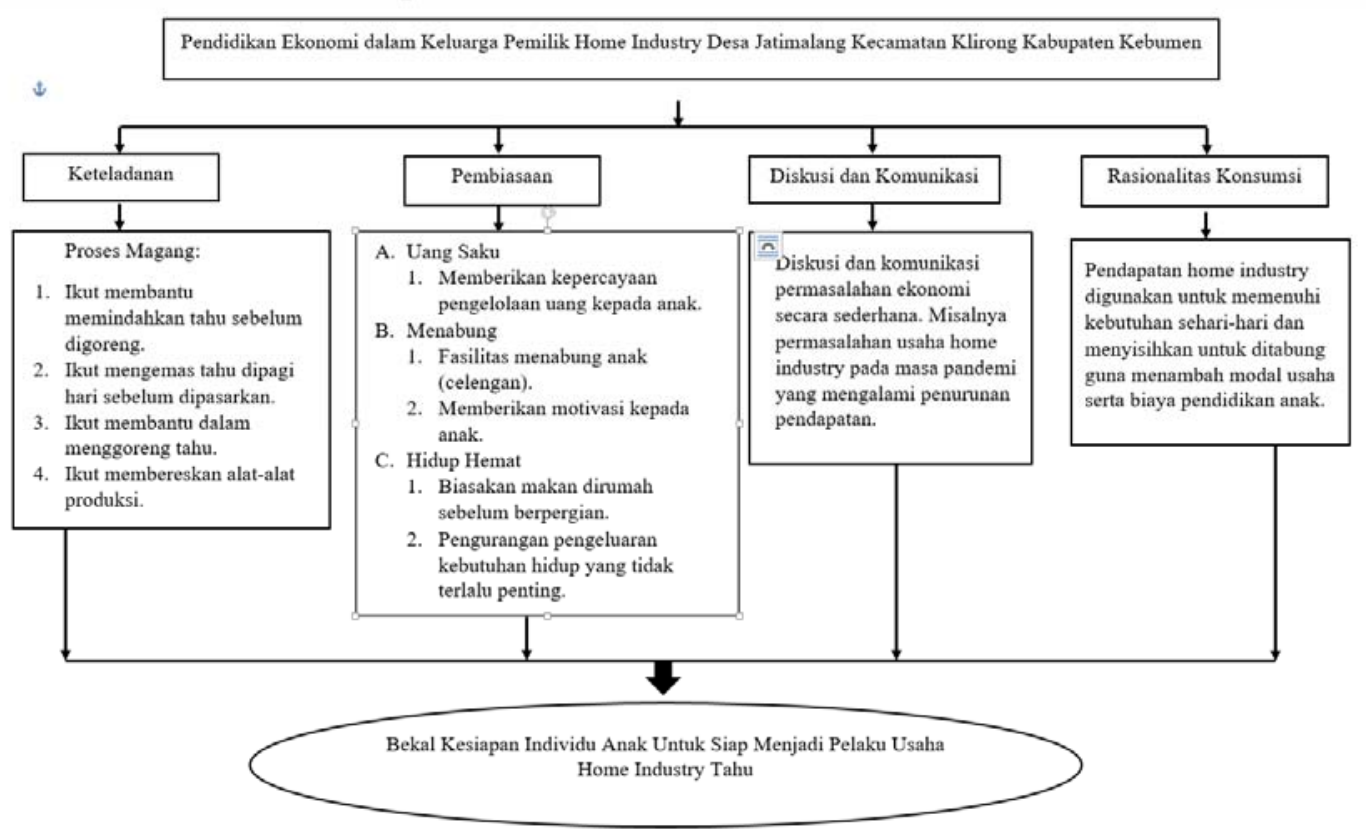

\section{Simpulan}

Intensitas pendidikan ekonomi dalam keluarga pada saat pandemi covid-19 lebih sering dilakukan orang tua dari pada sebelum adanya pandemi. Adanya pengurangan uang saku selama pandemi yang dikarenakan penurunan pendapatan serta pengurangan aktivitas diluar. Selain itu orang tua tetap memberikan fasilitas dan motivasi untuk menabung dan memberikan contoh hidup hemat. Orang tua tetap menyerahkan pengelolaan uang saku kepada anak, akan tetapi orang tua juga tetap ikut mengawasi agar tidak berlebihan. Komunikasi dan diskusi santai antara orang tua dengan anak untuk mengetahui tentang masalah ekonomi dalam keluarga sehingga antar anggota keluarga akan mengerti dengan keadaan yang ada. Orang tua dan anak tetap mendahulukan kebutuhan sebelum keinginan.

\section{Daftar Rujukan}

Akhyadi, A. S., \& Mulyono, D. (2018). Program Parenting dalam Meningkatkan Kualitas Pendidikan Keluarga (Program Pengabdian di Desa Karangpakuan, Kecamatan Darmaraja, Jurnal Pengabdian Kepada Masyarakat, 1, 8. (Online), (https://www.journal.ikipsiliwangi.ac.id/index.php/abdimassiliwangi/article/view/34),

Arfiliananda, M. A., \& Shofawati, A. (2018). Rasionalitas Konsumsi Petani Muslim pada Desa Sumber Kabupaten Probolinggo dalam Perspektif Islam. Jurnal Ekonomi Syariah Teori dan Terapan, 5(8), 623. (Online), (https://doi.org/10.20473/vol5iss20188pp623-633)

Furqon, I. K. (2018). Teori Konsumsi dalam Islam. Adzkiya : Jurnal Hukum dan Ekonomi Syariah, 6(1). (Online) (https://doi.org/10.32332/adzkiya.v6i1.1169). 
Helmawati. (2016). Pendidikan Keluarga (Teoris dan Praktis) (Nita Nur M). Bandung: PT REMAJA ROSDAKARYA.

Jones, P. (2010). Pengantar Teori-Teori Sosial: Dari Fungsionalisme hingga Post-modernisme. Yogyakarta: Yayasan Pustaka Obor Indonesia.

Lidyasari, A. T., \& Pd, M. (2013). Pola Asuh Otoritatif sebagai Sarana Pembentukan Karakter Anak dalam Setting Keluarga. 10.

Maharani, D., \& Hidayat, T. (2020). Rasionalitas Muslim: Perilaku Konsumsi dalam Prespektif Ekonomi Islam. 4. (Online), (http://jurnal.stie-aas.ac.id/index.php/jei/article/view/1374).

Mulyadi, S., \& Trizki, L. (2012). Financial Parenting: Menjadikan Anak Cerdas dan Cermat Mengelola Uang. Noura Books.

Mintarti, S.U. (2017). Pendidikan Keuangan dalam Keluarga, dalam Membentuk Sikap Berekonomi yang Rasional. (Online), (http://ekp.fe.um.ac.id/wp-content/uploads/2017/06/15.-Sri_Umi-Mintarti.pdf).

No, U. U. (20). Tahun 2003 tentang sistem pendidikan nasional.

Ngasifudin, M. (2018). Rasionalitas Ekonomi Islam. Al-Intaj: Jurnal Ekonomi dan Perbankan Syariah, 4(2).

Puspitawati, H. (2010). Pengaruh Karakteristik Sosial Ekonomi Keluarga terhadap Pola Asuh Belajar Siswa Sekolah Dasar dan Menengah Pertama. Jurnal Ilmu Keluarga dan Konsumen, 3(1), 46-55. (Online), (https://doi.org/10.24156/jikk.2010.3.1.46).

Siyamto, Y., \& Saputra, A. (2020). Analisis Keuangan Keluarga di Masa Pandemi Covid 19. 6. (Online), (http://ejournal.upbatam.ac.id/index.php/prosiding/article/view/3632).

Sugiri, D. (2020). Menyelamatkan Usaha Mikro, Kecil dan Menengah dari Dampak Pandemi Covid-19. Fokus Bisnis: Media Pengkajian Manajemen dan Akuntansi, 19(1), 76-86. (Online) (https://doi.org/10.32639/fokusbisnis.v19i1.575).

Statistik, B. P. (2020). Analisis hasil survei dampak covid-19 terhadap pelaku usaha. BP Indonesia, Analisis Hasil Survei Dampak Covid-19 terhadap Pelaku Usaha, 5.

Wahyono, H. (2001). Pengaruh Perilaku Ekonomi Kepala Keluarga Terhadap Intensitas Pendidikan Ekonomi di Lingkungan Keluarga. Disertasi tidak diterbitkan. Malang: PPs UM.

Wulandari, D., \& Narmaditya, B. S. (2015). Pengaruh Pendidikan Ekonomi Keluarga terhadap Perilaku Konsumsi Mahasiswa. 4. (Online). 